\title{
GC- MS Profiling of Ethnomedicinal Plant Hydrocotyle javanica Thunb
}

\author{
KRITHIKA NAMASIVAYAM ${ }^{1 *}$, ARUMUGASAMY KARUPPANAN ${ }^{2}$, \\ ABDUL KAFFOOR HABIBULLA ${ }^{3}$ and NANTHAKUMAR RANGASAMY4, \\ ${ }_{1,2,3,4}$ Department of Botany, Kongunadu Arts and Science College (Autonomous), \\ Coimbatore-641029,Tamilnadu,India. \\ 'Department of Plant Biology and Plant Biotechnology, Quaid-e-Millath Government College \\ for Women (Autonomous), Chennai-600002, Tamilnadu, India. \\ ${ }^{*}$ Corresponding author E-mail address: krithikadharma@ hotmail.com
}

http://dx.doi.org/10.13005/ojc/330465

(Received: April 17, 2017; Accepted: June 05, 2017)

\begin{abstract}
Hydrocotyle javanica Thunb. (Apiaceae), a medicinal herb of the southern Western Ghats was chosen for the elucidation of bioactive phyto constituents by GC-MS. This work was taken up to substantiate the ethnomedicinal uses by the natives and other indigeneous people from different regions by providing a database of bioactive constituents in this plant. The GC-MS analysis of the whole plant methanol extract identified thirty six bioactive compounds dominated by ten sesquiterpenes $(6.11 \%$ peak area). The maximum peak area of $33.37 \%$ was occupied by cinnamic acid- cyclohexyl ester. The first compound to be identified was $p$-cresol with retention time of 3.60 min, where as $\beta$-Sitosterol was the last compound which took longest retention time of $37.10 \mathrm{~min}$. The 36 compounds predominantly belonged to sesquiterpenes, fatty acids, terpenes, phenolics and steroids. These diverse active phyto constituents could offer protection against many ailments due to their wide range of activities.
\end{abstract}

Keywords: Hydrocotyle javanica, GC-MS, sesquiterpenes, ethnomedicinal

\section{INTRODUCTION}

Hydrocotyle javanica Thunb. commonly called as 'java pennywort' of the family Apiaceae is a procumbent herb growing in moist shaded places at high altitudinal regions in Nilgiris district, Tamilnadu, India. It is traditionally used in many regions of the world to cure many ailments. The ethnic communities of Manipur use the whole plant to cure stomach ulcer, urinary troubles, digestive complaints, dysentery and skin diseases'. The leaves are used in Akha's traditional medicine in China and Thailand as liniment on rashes ${ }^{2}$. The local vaidyas of Gavanal village at Hukkeri taluk of Belgaum district administer the entire plant for treating mental problems and to increase memory power ${ }^{3}$.Kurichia tribes inhabiting Vythiri taluk of Wayanad district apply the juice of the whole plant on the chest to cure asthma and fits ${ }^{4}$. 
Ethnic groups called 'Girijana' of Kodagu district in Karnataka ingest the crushed whole plant in butter milk to cure dysentery ${ }^{5}$. Leaves of $H$. javanica are used as a blood purifier by the tribes of Thiashola, Manjoor, Nilgiris district ${ }^{6}$. In Manipur this plant is traditionally used as an aperient, against fever, and its paste is applied in skin diseases ${ }^{7}$. Traditionally, the fresh plant parts of $H$. javanica are crushed and ingested orally to cure sores of throats and lungs. Leaf juice is often used as eye drops to cure eye infection and leaf paste was used in dressing of wounds to reduce swelling and juice of shoots can treat gastritis and constipation as reported to be used by local people of Darjeeling ${ }^{8}$.

The ethno-medicinal uses of $H$. javanica are appreciable but the active principles involved in these treatments have not yet been tapped scientifically by experimental analysis. Thus, these traditional pharmacological uses had been the driven force for the present investigation to determine and identify the bioactive phytocompounds in the whole plant methanol extract of $H$. javanica by Gas Chromatography-Mass Spectrometry (GC-MS) analysis.

\section{MATERIALS AND METHODS}

\section{Plant collection and identification}

$H$. javanica was collected from the Aravenu region of Nilgiris district in Tamil nadu and identified by Dr. M. Murugesan, Scientist B, BSI, Shillong. A voucher specimen (KASC/H/1862) has been deposited at the herbarium maintained by Kongunadu Arts and Science College, Coimbatore, Tamil nadu, India.

\section{Extraction}

The washed and air dried whole plants of H. javanica were powdered in a pulverizer and about $250 \mathrm{~g}$ of this powder were defatted in petroleum ether. The defatted powder was subjected to Soxhlet hot extraction using $750 \mathrm{~mL}$ methanol for 6-7 hrs, being a delicate plant. It yielded $8.2 \mathrm{~g}$ of pale-yellow coloured, semi-solid form of extract. The extracts were reduced to dry residue and stored in aseptic conditions in the refrigerator for further studies.

\section{GC-MS analysis and Instrumentation}

The methanol extract of $H$. javanica was analyzed through Gas Chromatography-Mass Spectrometry/ Mass Spectrometry for identification of different compounds. GC-MS are unanimously accepted methods for the analysis of constituents of herbal medicines, due to their sensitivity, stability and high efficiency. The analysis of pharmacologically active components in herbal medicines by gas chromatography is very important in elucidating the composition and relative concentration of the organic compounds ${ }^{9}$. GC-MS analysis was carried out using a Scion 436-GC Bruker TQ quadrupole GC -MS system with a built in National Institute of Standards and Technology (NIST) library Version 11. The GC-MS system was equipped with a $30 \mathrm{~m} \times 0.25 \mathrm{~mm}$ ID $\times 0.25 \mu \mathrm{m}$ df column BR-5MS (5\% Diphenyl / 95\% Dimethyl poly siloxane). To separate the extracts, the capillary column temperature was programmed as follows: $110^{\circ} \mathrm{C}$ hold for $3.50 \mathrm{~min}$; Up to $200{ }^{\circ} \mathrm{C}$ at the rate of $10^{\circ} \mathrm{C} / \mathrm{min}$-No hold; Up to $280^{\circ} \mathrm{C}$ at the rate of $5^{\circ} \mathrm{C} / \mathrm{min}-12 \mathrm{~min}$ hold. The injector temperature was set at $280^{\circ} \mathrm{C}$. The carrier gas used was helium at a flow rate of $1 \mathrm{~mL} / \mathrm{min}$. The concentrated extracts were injected with a $2 \mu \mathrm{L}$ volume using a split (10:1) injection approach. The instrument was operated using an electron ionization source with the Inlet line temperature at $290^{\circ} \mathrm{C}$ and ion source temperatures set at $250^{\circ} \mathrm{C}$. The ionization potential (Electron energy) was $70 \mathrm{eV}$. The MS data were collected from Mass scan (m/z) 50-500 amu with a solvent delay of 0-3.5 min. Total MS running time was $40.50 \mathrm{~min}$. Data acquisition and processing was performed using software MS work station 8 . The separated components were identified through mass spectral comparison with a built in NIST - 11 MS library.

\section{RESULTS AND DISCUSSION}

\section{Bioactive constituents in $\mathrm{H}$. javanica}

The GC-MS analysis of $\mathrm{H}$. javanica whole plant revealed the presence of thirty six compounds (phytochemical constituents) that could probably contribute to the medicinal quality of the plant (Table 1). Many of these compounds are biologically active against cancer, tumours, inflammation, pyrexia, microbes, fungus (Table 2). About ten sesquiterpenes were identified that occupied $6.11 \%$ peak area. These are $\delta$-Elemene, $\tau$-Elemene, Caryophyllene, cis- $\beta$-farnesene, Humulene, $\gamma$-Elemene, $\beta$-Nerolidiol, (+)-Spathulenol, (-)-Spathulenol, Isoaromadendrene. 
Squalene (triterpene), phytol (diterpene), two steroids Stigmasterol and $\beta$-Sitosterol, Linoleic acid, Oleic acid methyl ester, Palmitic acid methyl ester, p - Cresol (Phenol), Cinnamic acid cyclohexyl ester and two ketone compounds were among the other compounds identified. The maximum peak area of $33.37 \%$ was occupied by Cinnamic acid- cyclohexyl ester (Fig. 1). The peak area, retention time and molecular formula confirmed the identification of the phytochemical compounds. The first compound identified with less retention time of $3.60 \mathrm{~min}$ was $p$-cresol, whereas $\beta$-Sitosterol was the last compound which took longest retention time of $37.10 \mathrm{~min}$ to identify. The biological activities listed are based on Dr. Duke's Phytochemical and Ethnobotanical Databases.

The preliminary qualitative phytochemical studies on methanol extract of H.javanica evinced the presence of alkaloids, coumarins, flavonoids, glycosides, phenols, saponins, terpenoids and tannins as the main bioactive constituents and have already been reported ${ }^{10}$.

In the present study major class of compounds were the sesquiterpenes, terpenes, fatty acids steroids, ketones and phenolic compounds. However, cinnamic acid cyclo ester and a ketone compound (S.No.34 and 33, Table 1), occupied

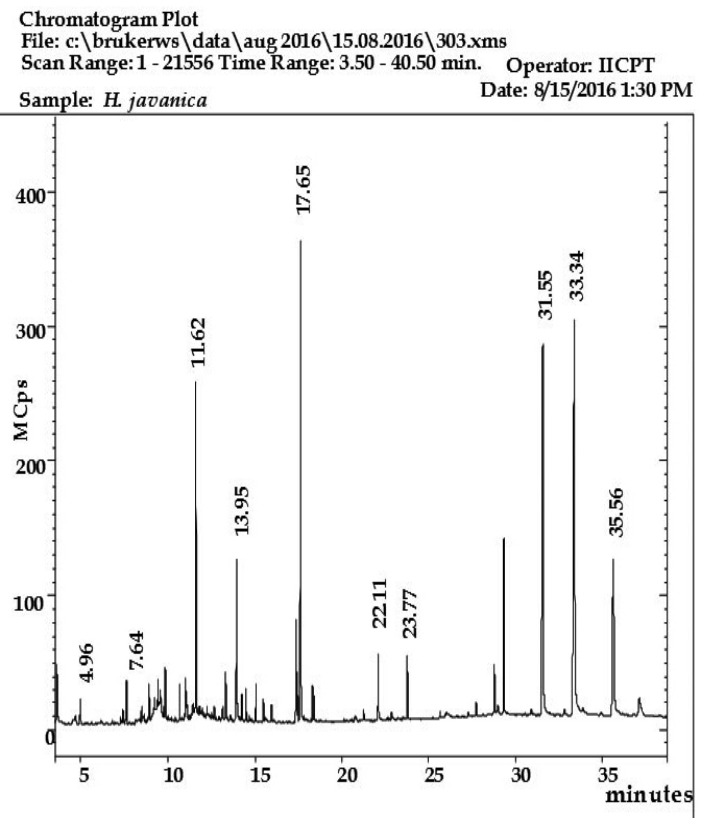

Fig.1: GC-MS Chromatogram of $\boldsymbol{H}$. javanica major peak areas. The fatty acids were palmitic, oleic and linoleic acids with cancer preventive and hypocholesterolemic activities, specifically. Of the 36 compounds identified in the methanol extract of $H$.javanica, 10 belonged to the class of sesquiterpenes, 5 fatty acids, 4 terpenes, two ketones, one flavonoid and phenolics that possessed notable biological activities. The cinnamic acid ester that occupied the major area was known for its bioactivities such as antioxidant, analgesic and anti-inflammatory. On the whole 20 constituents were known for their anti-inflammatory activity, 14 for their anti-tumour or cancer preventive activities, 11 for their analgesic, 10 with sedative action, 10 antimicrobial and 10 antibacterial. Hence the present ethnomedicinal plant can be adjudged as a potent anti-inflammatory agent. Also, it could be used as a sedative, anticancer, analgesic and anti-microbial agent. The Apiaceae taxa are distinguishable by the occurrence of umbelliferose, and polyacetylenes, several specific phenols, phenylpropanoids, terpenes, saponins and coumarins in fruits, leaves and/or roots ${ }^{11}$. Petroselinic acid and Linoleic acid were the fatty acid constituents reported to be present in all of the Apiaceae genera ${ }^{12}$. The major components of leaf and flower essential oil from $H$. bonariensis were the monoterpenes (53.6\%) and sesquiterpenes (10.5\%) 13. The aerial parts of H.umbellata L. (Apiaceae) yielded $0.025 \%$ of essential oil through hydrodistillation which was analysed by capillary GC-FID and GC/MS. $92.1 \%$ of the oil were characterized by twenty-one constituents. The major compounds were germacrene $\mathrm{D}(26.0 \%)$, $\beta$-sesquiphellandrene (17.5\%) and $\beta$-bisabolene $(16.5 \%)$ 14. The essential oil from the coriander herb contained the highest amount of aliphatic aldehydes, among which decanal, E-2-dodecanol and E-2decenol had the highest percentages ${ }^{15}$. GC-MS spectrum of ethanolic leaf extract of Centella asiatica had shown the presence of the major components methyl pyromeconic acid (maltol) (RT: 5.183 min), methoxy vinyl phenol (RT: $8.617 \mathrm{~min}), 3^{\prime}, 5^{\prime}-$ Dimethoxyacetophenone (RT: $11.867 \mathrm{~min}$ ), BetaD-Ribofuranoside (RT: $10.675 \mathrm{~min}$ ), cyclohexane carboxylic acid (RT: $12.825 \mathrm{~min}$ ), 5-methoxy- 2,2,8,8tetramethyl-acetate (RT: $25.73 \mathrm{~min}$ ) and Nobiletin (RT: $27.275 \mathrm{~min}$ )16. GC-MS of the petroleum ether extract of Magydaris tomentosa flowers (Desf.) W. D. J. Koch mainly constituted the furanocoumarins such as xanthotoxin, xanthotoxol, isopimpinellin, and bergaptene along with other coumarins 
Table 1: GC-MS identification of the phyto compounds in Hydrocotyle javanica

\begin{tabular}{|c|c|c|c|c|c|}
\hline S.No & RT(min) & $\begin{array}{l}\text { Name of the } \\
\text { compound }\end{array}$ & $\begin{array}{l}\text { Molecular } \\
\text { Formulae }\end{array}$ & MW & P A\% \\
\hline 1 & 3.60 & p-Cresol & $\mathrm{C}_{7} \mathrm{H}_{8} \mathrm{O}$ & 108 & 3.10 \\
\hline 2 & 4.96 & Cyclohexanone, 2-acetyl- & $\mathrm{C}_{8} \mathrm{H}_{12}^{8} \mathrm{O}_{2}$ & 140 & 1.39 \\
\hline 3 & 7.42 & $\begin{array}{l}\text { Bicyclo(3.1.1)heptane-2,3-diol, } \\
\text { 2,6,6-trimethyl- }\end{array}$ & $\mathrm{C}_{10}^{8} \mathrm{H}_{18}^{2} \mathrm{O}_{2}$ & 170 & 0.17 \\
\hline 4 & 7.64 & $\delta$-Elemene & $\mathrm{C}_{15} \mathrm{H}_{24}$ & 204 & 0.90 \\
\hline 5 & 8.43 & $\tau$-Elemene & $\mathrm{C}_{15}^{15} \mathrm{H}_{24}^{24}$ & 204 & 0.10 \\
\hline 6 & 8.52 & $\begin{array}{l}\text { Furan-2-carbohydrazide, } \\
\text { N2-(3-indolylmethylene)- }\end{array}$ & $\mathrm{C}_{14}^{15} \mathrm{H}_{11}^{24} \mathrm{~N}_{3} \mathrm{O}_{2}$ & 253 & 0.31 \\
\hline 7 & 8.62 & $\begin{array}{l}\text { 2(3H)-Naphthalenone, 4,4a,5,6,7,8 } \\
\text {-hexahydro-1-methoxy- }\end{array}$ & $\mathrm{C}_{11} \mathrm{H}_{16} \mathrm{O}_{2}$ & 180 & 0.10 \\
\hline 8 & 8.93 & Caryophyllene & $\mathrm{C}_{15} \mathrm{H}_{24}$ & 204 & 0.39 \\
\hline 9 & 9.23 & cis- $\beta$-Farnesene & $\mathrm{C}_{15}^{15} \mathrm{H}_{24}^{24}$ & 204 & 0.41 \\
\hline 10 & 9.42 & Humulene & $\mathrm{C}_{15}^{15} \mathrm{H}_{24}$ & 204 & 0.72 \\
\hline 11 & 9.58 & $\begin{array}{l}\text { (2,6,6-Trimethylcyclohex-1- } \\
\text { enylmethanesulfonyl)benzene }\end{array}$ & $\mathrm{C}_{16}^{15} \mathrm{H}_{22}^{24} \mathrm{O}_{2} \mathrm{~S}$ & 278 & 0.41 \\
\hline 12 & 9.91 & $\gamma$-Elemene & $\mathrm{C}_{15} \mathrm{H}_{24}$ & 204 & 0.00 \\
\hline 13 & 10.68 & $\beta$ - Nerlidiol & $\mathrm{C}_{15}^{15} \mathrm{H}_{26}^{24} \mathrm{O}$ & 222 & 0.34 \\
\hline 14 & 11.10 & $\begin{array}{l}\text { 1H-Cycloprop[e]azulen-7-ol, decahydro-1,1,7 } \\
\text {-trimethyl-4-methylene-, [1ar- } \\
(1 \mathrm{a} \alpha, 4 \mathrm{a} \alpha, 7 \beta, 7 \mathrm{a} \beta, 7 \mathrm{~b} \alpha)]-\end{array}$ & $\mathrm{C}_{15} \mathrm{H}_{24} \mathrm{O}$ & 220 & 0.11 \\
\hline 15 & 11.62 & (-)-Spathulenol & $\mathrm{C}_{15} \mathrm{H}_{24} \mathrm{O}$ & 220 & 2.86 \\
\hline 16 & 13.33 & Isoaromadendrene epoxide & $\mathrm{C}_{15} \mathrm{H}_{24} \mathrm{O}$ & 220 & 0.28 \\
\hline 17 & 13.95 & $\begin{array}{l}\text { 3,7,11,15-Tetramethyl-2- } \\
\text { hexadecen-1-ol }\end{array}$ & $\mathrm{C}_{20}^{15} \mathrm{H}_{40} \mathrm{H}^{2} \mathrm{O}$ & 296 & 2.19 \\
\hline 18 & 14.26 & 7-Hexadecyn-1-ol & $\mathrm{C}_{16} \mathrm{H}_{30} \mathrm{O}$ & 238 & 0.34 \\
\hline 19 & 14.49 & Phytol, acetate & $\mathrm{C}_{20}{ }_{20} \mathrm{H}_{42} \mathrm{O}_{2}$ & 338 & 0.71 \\
\hline 20 & 15.07 & $\begin{array}{l}\text { Hexadecanoic acid, } \\
\text { methyl ester }\end{array}$ & $\mathrm{C}_{17}^{22} \mathrm{H}_{34}^{42} \mathrm{O}_{2}^{2}$ & 270 & 0.71 \\
\hline 21 & 15.50 & Dibutyl phthalate & $\mathrm{C}_{16} \mathrm{H}_{22} \mathrm{O}_{4}$ & 278 & 1.59 \\
\hline 22 & 15.97 & n-Propyl 11-octadecenoate & $\mathrm{C}_{21}^{16} \mathrm{H}_{40}^{22} \mathrm{O}_{2}^{4}$ & 324 & 0.19 \\
\hline 23 & 17.37 & $\begin{array}{l}9,12 \text {-Octadecadienoic } \\
\text { acid }(Z, Z)-\end{array}$ & $\mathrm{C}_{18} \mathrm{H}_{32} \mathrm{O}_{2}$ & 280 & 2.04 \\
\hline 24 & 17.46 & $\begin{array}{l}\text { 9-Octadecenoic acid (Z)-, } \\
\text { methyl ester }\end{array}$ & $\mathrm{C}_{19} \mathrm{H}_{36} \mathrm{O}_{2}$ & 296 & 0.64 \\
\hline 25 & 17.65 & Phytol & $\mathrm{C}_{20} \mathrm{H}_{40} \mathrm{O}$ & 296 & 8.81 \\
\hline 26 & 18.33 & 9,12-Octadecadienoic acid (Z,Z)-, methyl ester & $\mathrm{C}_{19} \mathrm{H}_{34} \mathrm{O}_{2}$ & 294 & 0.41 \\
\hline 27 & 18.42 & Ethyl Oleate & $\mathrm{C}_{20} \mathrm{H}_{38}^{34} \mathrm{O}_{2}^{2}$ & 310 & 0.22 \\
\hline 28 & 21.27 & 2H-Pyran, 2-(7-heptadecynyloxy)tetrahydro- & $\mathrm{C}_{22} \mathrm{H}_{40} \mathrm{O}_{2}$ & 336 & 0.12 \\
\hline 29 & 22.11 & 1,4-Benzenedipropanol, $\alpha, \alpha^{\prime}, \gamma, \gamma, \gamma^{\prime}, \gamma^{\prime}$-hexamethyl- & $\mathrm{C}_{18}^{22} \mathrm{H}_{30}^{40} \mathrm{O}_{2}^{2}$ & 278 & 0.49 \\
\hline 30 & 23.77 & Z,Z-3,15-Octadecadien-1-ol acetate & $\mathrm{C}_{20} \mathrm{H}_{36} \mathrm{O}_{2}$ & 308 & 3.33 \\
\hline 31 & 27.72 & Squalene & $\mathrm{C}_{30} \mathrm{H}_{50}$ & 410 & 0.33 \\
\hline 32 & 28.76 & 1,3-Bis(cinnamoyloxymethyl) adamantine & $\mathrm{C}_{30} \mathrm{H}_{32} \mathrm{O}_{4}$ & 456 & 1.74 \\
\hline 33 & 31.55 & $\begin{array}{l}\text { 2(3H)-Furanone, 3,4-bis(1,3-benzodioxol } \\
-5 \text {-ylmethyl)dihydro-, (3R-trans)- }\end{array}$ & $\mathrm{C}_{20}^{30} \mathrm{H}_{18}^{32} \mathrm{O}_{6}^{4}$ & 354 & 30.07 \\
\hline 34 & 33.34 & Cinnamic acid, cyclohexyl ester & $\mathrm{C}_{15} \mathrm{H}_{18} \mathrm{O}_{2}$ & 230 & 33.37 \\
\hline 35 & 35.56 & Stigmasterol & $\mathrm{C}_{29} \mathrm{H}_{48} \mathrm{O}$ & 412 & 1.11 \\
\hline 36 & 37.10 & $\beta$-Sitosterol & $\mathrm{C}_{29}^{29} \mathrm{H}_{50}^{40} \mathrm{O}$ & 414 & 0.01 \\
\hline
\end{tabular}

$\mathrm{RT}=$ Retention time; $\mathrm{MW}=$ Molecular weight; $\mathrm{PA} \%=$ Peak Area $\%$ 
Table 2: Nature and activities of the GC-MS identified phytocompounds from $\boldsymbol{H}$. javanica

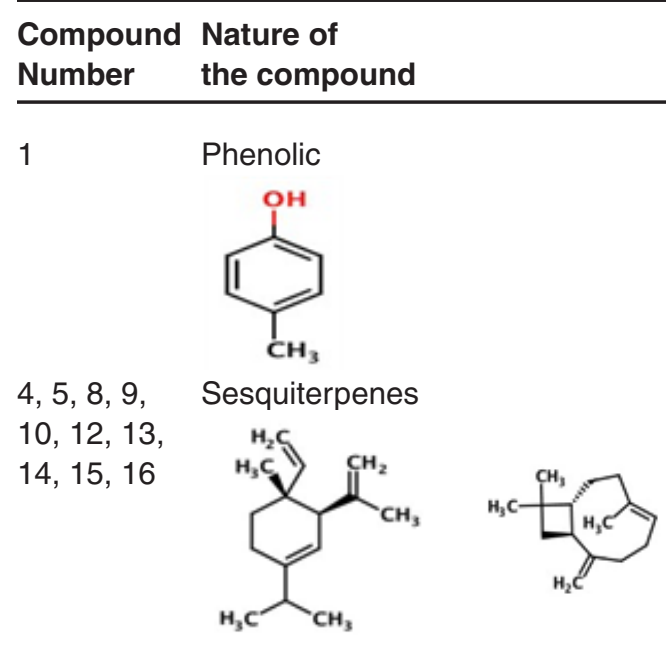

25, $31 \quad$ Terpenes<smiles>[CH]C([CH])CCCC(C)CCC[C@@H](C)CCCC(C)=CCO</smiles>

34

Cinnamic acid ester

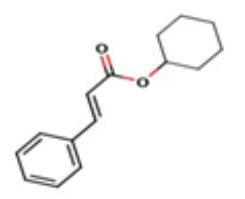

24, 27, 26 Oleic acid, Linoleic acid

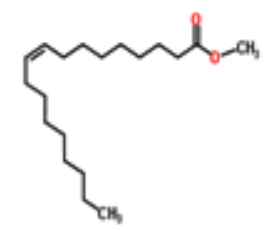

8

Flavonoid fraction

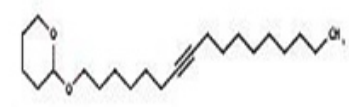

35,36

Steroids

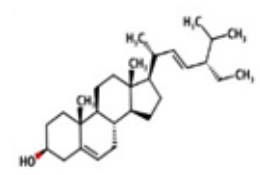

\section{Bioactivity}

Antioxidant,

Antimicrobial,

Anti-inflammatory

Anti-tumor, Analgesic,

Antibacterial,

Anti-inflammatory,

Sedative, Fungicide

Antimicrobial, Anti-

inflammatory,

Anticancer, Diuretic

Antioxidant,

Antimicrobial, Anti-

inflammatory,

Analgesic

Cancer preventive,

Flavor,

Hypocholesterolemic,5-

Alpha reductase

inhibitor,

Antiandrogenic,

Perfumery,

Insectifuge,Anti-

inflammatory

Antioxidant,

25,26

Antimicrobial,

Anti-inflammatory

Anti-inflammatory,

27

Reference

No.

8

21,22

23

24

25

Sedative,

Antihepatotoxic ,

Cancer-preventive

Antiviral, Ovulant,

Estrogenic

Hypocholesterolemic 
and bergaptene along with other coumarins such as 7-methoxy-8-(2-formyl-2-methylpropyl) coumarin and osthole17. The sesquiterpenes and few other compounds identified here have also been reported from the essential oil of C. asiatica (L.) Urban.,by different researchers as given in a review article ${ }^{18}$. Hydro-distilled volatile oils from crushed dry aerial parts of Prangos latiloba Korov growing wild in Sabzevar (Iran), were analysed by GC and GC/ MS which reported the presence of twenty one compounds constituting $84.9 \%$ of the oil from the aerial parts. The main components were geranial $(26.8 \%)$, methyl chavicol (22.8\%) and neral (22.6\%)19.The GC-MS analysis of water distilled essential oils from the crushed fruits and aerial parts of Bilacunaria anatolica A. Duran inhabiting regions of Turkey were characterized with $\alpha$-pinene $(25.7 \%$, $28.6 \%)$, camphene (18.7\%, 10.7\%), $\beta$-caryophyllene $(10.2 \%, 10.3 \%)$ and caryophyllene oxide $(2.6 \%$, $13.4 \%)$, respectively ${ }^{20}$.

\section{CONCLUSION}

Most of the Apiaceae members are aromatic due to rich content of essential oils and hence GCMS of essential oils have been analysed and reported earlier, but the GC-MS of whole plant extract has not been reported much. This as a first study on GC-MS analysis of $H$. javanica has provided clarity into the bioactive constituents aiding in the ethnopharmacological uses. The scope of the present study warrants the isolation and characterization of the important lead compounds, which will be taken up in the future. This plant could be promising as a valuable and cost effective herbal medicine whose potentials can be tapped for therapeutic uses.

\section{ACKNOWLEDGMENTS}

The authors thank i) Dr.M.Murugesan, Scientist B, BSI, Shillong, India, ii) the UGC - SERO, Hyderabad, India for the FDP contingency grant in the XII plan (FIP-TNMD030/001(TF)/ BOTANY/ PH.D/XII PLAN/2014-15 Dtd: OCTOBER 2015), iii) Dr.V.R.Mohan, Associate Professor and Head, Department of Botany, V.O.Chidambaram College, Tuticorin, Tamilnadu, India, for helping with analysis iv) Mr. S. Kumaravel, Senior Scientist, Indian Institute of Crop Processing Technology (Ministry of food Processing Industries, Government of India) Thanjavur, Tamilnadu for the Instrumentation and analysis.

\section{REFERENCES}

1. Ashalatha, D. K.; Khan, M. L.; Tripathi, R. S. Indian J. Trad. Knowled. 2005,4(1),21-32.

2. Inta, A.; Shengji, P.; Balslev, H.; Wangpakapattanawong, P.; Trisonthi, C. J Ethnopharmacol.2008, 116, 508-17.

3. Jyoti S Kawalekar. Int. J. Phytother. Res.2011,1(1), 1-7.

4. Prasad, A.G.; Shyma, T.B. J. Med. PI. Res.2013, 7, 1439-51.

5. Lingaraju, D. P.; Sudarshana, M.S.; Rajashekar, N.J. Pharm. Res.2013, 6/7 (2), 284.

6. Sharmila,S.; Kalaichelvi, K.; Rajeswari, M; Anjanadevi, M. Int. J. Plan. Ani.Env. Sci. 2014, 4(3), 14-22.

7. Khaling, M.; Suresh, K.; Vandana. Int. J. Herb. Med. 2014,2(1), 1-12.

8. Mandal, M.; Saikat, P.;Md. Raihan, U.; Mohabul, A. M.; Sukhendu, M.; Vivekananda, M. Asian Pac. J. Trop. Dis.2016, 6(1), 54-62.

9. Liang, Y. Z.; Xie, P.; Chan, K.J. Chromatogr B.
2004, 812, 53-70.

10. Krithika, N.; Arumugasamy, K.J. Environ. Nanotechnol. 2016, 5(4), 27-33

11. Hegnauer R. Chemotaxonomie der Pflanzen (Vol 9),BirkhäuserVerlag, Berlin, Germany. 1990, 663-714.

12. Vioque J, Pastor, J.E.; Vioque, E. J. Am. Oil Chemist Society. 1993, 70(11),1157-58.

13. Huong, T. N.L.; Phung, K. N.; Suong, N. N. Química Nova. 2009, 32, 2373-6.

14. Rojas, L. B.; Usubillaga, A.; Rondón, J.; Vit, P. J Essent. Oil Res. 2009, 21, 253-54.

15. Renata, N.W. ActaAgrobotanica.2013, 66(1), 53-60

16. Kavisa, G.;Indra,N.Int. J. Pharm. Sci. Rev. Res.2014, 29, 328-34.

17. Autore, G.; Stefania, M.; Carmen, F.; Maurizio, B.; Sergio, R.; Mariem, B. J.; Felice, S. Molecules 2015, 20,1571-78.

18. Supawan, R.; Patchanee, Y. Oriental JChem. 
2015, 31, 2453-59.

19. Aklaghi, H. Nat Prod. Chem.2015, 3(1), 1-4

20. Kurkcuoglu, M. JEssent. Oil Bearing Plants. 2016, 19(2), 379-83.

21. Geroushi, A.;Auzi, A. A.; Elhwuegi, A. S.; Elzawam, F.; Elsherif, A.;Nahar, L.;Sarker, S.D. Phytother. Res.2011, 25, 774-77.

22. Matejic, J.; Z Sarac, Z; Randelovic, V. Biotechnol. Biotechnol. Eq.2010, 24(1), 95100.

23. Mandal, S.; Manisha, M. Asian Pac. J. trop.
Biomed. 2015, 5(6), 421-28.

24. Prateek, S. J. Chem. Pharm. Res., 2011, 3(2): 403-23.

25. Li, A.N.; Li, S.; Zhang, Y.J.; Xu, X. R.; Chen, Y.M.; Li, H.B.; Nutrients.2014, 6, 6020-47.

26. Maulidiani; Faridah, A.; Alfi, K.; Khozirah, S.; Nordin, H. L. Indust. Crops Prod. 2014,55, 238-47.

27. Salem, B.S.; Jabrane, A.; Harzallah-Skhiri, F.; Jannet, B.H. Bioorg. Med. Chem. Lett. 2013, 23, 4248-52. 